\title{
Effects of light stress on the growth of the epiphytic orchid Cattley a forbesii Lindl. X Laelia tenebrosa Rolfe
}

\author{
GIULIO C. STANCATO ${ }^{1,4}$, PAULO MAZZAFERA ${ }^{2}$ and MARCOS S. BUCKERIDGE ${ }^{3}$
}

(received: August 8, 2001; accepted: March 27, 2002)

\begin{abstract}
Effects of light stress on the growth of the epiphytic orchid Cattleya forbesii Lindl. X Laelia tenebrosa Rolfe). Considering the performance of CAM epiphytes under high levels of radiation or in shaded environments, with growth rate proportional to light intensity, the objective of this work was to evaluate the effects of long-term light stress on the growth of a Brazilian epiphytic orchid, Cattleya forbesii Lindl. X Laelia tenebrosa Rolfe. Two groups of plants were used in the first experiment, one under $90 \%\left(\cong 1,650 \mu \mathrm{mol} . \mathrm{m}^{-2} . \mathrm{s}^{-1}\right)$ of Photosynthetically Active Radiation (PAR) and the other maintained under $22.5 \%\left(\cong 400 \mu \mathrm{mol} \cdot \mathrm{m}^{-2} \cdot \mathrm{s}^{-1}\right)$. In the second experiment the diffusive resistance, transpiration rate and fluorescence levels were monitored for plants that were under $22.5 \%$ of PAR, under $90 \%$ and plants transferred from 22.5 to $90 \%$. Our results show that light intensity interfered with growth and development of this orchid. Data on the changes in pseudobulb volume throughout the time course of growth suggest that water and reserves stored in the back shoots are translocated to the current shoot. Regarding stomatal resistance, plants under $22.5 \%$ of PAR reached a largest stomatal aperture during the night, whereas those under $90 \%$ only after dawn. After transfer from $22.5 \%$ PAR to $90 \%$ PAR the ratio of $\mathrm{F}_{\mathrm{v}} / \mathrm{F}_{\mathrm{m}}$ decreased from approximately 0.8 to 0.7 . This suggests the limitation of photoprotection mechanisms in the leaf and the results observed after the transfer of plants from $22.5 \%$ to $90 \%$ reinforce the possibility that a photoinhibition is reflected in a decrease in growth rate.
\end{abstract}

RESUMO - (Efeitos do estresse luminoso sobre o crescimento da orquídea epífita Cattleya forbesii Lindl. X Laelia tenebrosa Rolfe). Baseado no desempenho de plantas epífitas com metabolismo CAM, em ambientes sombreados ou sob alta irradiância, com taxa de crescimento proporcional à intensidade luminosa, o objetivo deste trabalho foi avaliar os efeitos do estresse luminoso prolongado sobre o crescimento de uma orquídea epífita brasileira, Cattleya forbesii Lindl. X Laelia tenebrosa Rolfe. No primeiro experimento, dois grupos de plantas foram empregados, sendo que um grupo foi mantido sob $90 \%$ da radiação fotossinteticamente ativa $($ RFA $)\left(\cong 1.650 \mu \mathrm{mol} \cdot \mathrm{m}^{-2} \cdot \mathrm{s}^{-1}\right)$ e o outro sob $22,5 \%\left(\cong 400 \mu \mathrm{mol} \cdot \mathrm{m}^{-2} \cdot \mathrm{s}^{-1}\right)$. No segundo experimento, a resistência difusiva, a taxa de transpiração e os níveis de fluorescência foram monitorados em plantas sob $90 \%$ da RFA, 22,5\% da RFA e em plantas transferidas de 22,5 para 90\% da RFA. Nossos resultados indicam que a alta intensidade luminosa reduziu o crescimento e o desenvolvimento desta orquídea. Dados da variação no volume dos pseudobulbos durante o crescimento sugerem que a água e as reservas armazenadas nos pseudobulbos mais velhos podem ter sido transferidas para o pseudobulbo mais novo. Considerando a resistência estomática, os estômatos das plantas submetidas à 22,5\% da RFA atingiram a sua maior abertura durante à noite, enquanto que nas plantas sob $90 \%$ da RFA a maior abertura estomática ocorreu somente ao amanhecer. Após a transferência de $22,5 \%$ para $90 \%$ do RFA, a razão $F_{v} / F_{m}$ diminuiu de aproximadamente 0,8 para 0,7. Isto sugere a restrição dos mecanismos de fotoproteção na folha e os resultados observados, após a transferência de plantas de $22,5 \%$ para $90 \%$ do RFA, reforçam a possibilidade de que a fotoinibição implicou numa diminuição da taxa de crescimento.

Key words - Photoinhibition, storage, orchids, pseudobulb

\section{Introduction}

Studies involving comparison of light-saturation curves showed that some epiphytic orchids present characteristics of sun plants, or intermediate plants (Lüttge 1989). In general, CAM epiphytes show a better

\footnotetext{
1. Instituto Agronômico, Centro de Horticultura, Caixa Postal 28, 13001-970 Campinas, SP, Brasil.

2. Universidade Estadual de Campinas, Instituto de Biologia, Caixa Postal 6109, 13083-970 Campinas, SP, Brasil.

3. Instituto de Botânica, Seção de Fisiologia e Bioquímica de Plantas, Caixa Postal 4005, 01061-970 São Paulo, SP, Brasil.

4.

Corresponding author: stancato@iac.br
}

performance under high light intensity when compared to epiphytes with $\mathrm{C}_{3}$ metabolism (Winter et al. 1983). However, few species of orchids resist direct exposure to sunlight for long periods, since photoinhibition may occur (Osmond 1978, Winter et al. 1983).

Even though the majority of CAM type epiphytes are found in sites with high light intensity, there are also CAM type plants adapted to shaded environments (Winter et al. 1983). Under natural conditions, high light intensity provokes an increase in leaf temperature, which intensifies deacidification and increases daytime CAM rhythm (Osmond 1978).

In practice, the evaluation of photosynthetic performance of CAM type plants is through 
fluorescence measurements, since it has been demonstrated experimentally that the $F_{v} / F_{m}$ ratio is proportional to the photosynthetic rate of intact leaves, measured as $\mathrm{CO}_{2}$ fixation or $\mathrm{O}_{2}$ evolution (Björkmam \& Demmig 1987). This ratio is affected by stress, particularly by photoinhibition.

Photoinhibition has been observed when plants are exposed to three different conditions: 1) when they are exposed to a level of irradiance greater than that under which they have been growing; 2) when they are temporarily subjected to a low level of $\mathrm{CO}_{2}$ and 3) when maintained at temperatures below $10{ }^{\circ} \mathrm{C}$, even under regular level of irradiance (Björkmam \& Demmig 1987). The occurrence of photoinhibition may be promptly determined by measuring the photosynthetic transport of electrons, by the exchange of $\mathrm{O}_{2}$ or through the levels of fluorescence of chlorophyll $a$ (Winter \& Gademann 1991, Keiller et al. 1994).

Recently, Stancato et al. (2001) found that pseudobulbs of the epiphytic orchid Cattleya forbesii $\mathrm{X}$ Laelia tenebrosa store glucomannan as a main storage compound. This polymer is mobilised as a result of several abiotic factors of stress and was shown to affect the photosynthetic system.

In the present work, we followed some growth and development parameters of the epiphytic orchid C. forbesii X L. tenebrosa under two different conditions of irradiance with the aim of finding long-term changes provoked by different light intensities. The results showed that high light intensities induced photoinhibition and the gas exchanges were significantly affected. These results are discussed regarding the possible effects of light regime on the incorporation and partitioning of dry mass among the parts of the plant.

\section{Material and methods}

The trials were conducted with plants $\left(\mathrm{F}_{1}\right)$ of Cattleya forbesii Lindl. X Laelia tenebrosa Rolfe, in São Paulo, Brazil $\left(22^{\circ} 53^{\prime} \mathrm{S}\right.$ and $\left.47^{\circ} 05^{\prime} \mathrm{W}\right)$, which were obtained through artificial pollination and asymbiotic culture in vitro (Knudson 1946).

The plants were watered on alternate days, and once a month each one received $200 \mathrm{~mL}$ of Hoagland \& Arnon (1950) solution soon after watering.

Two groups of plants were kept side by side on the top of benches in a greenhouse during approximately three years. One of the groups was covered with a $75 \%$ shade cloth whereas the other received no cover. The monitoring of incident solar radiation showed that, from the total of
Photosynthetically Active Radiation (PAR), the incidence was $90 \%\left(\cong 1,650 \mu \mathrm{mol} . \mathrm{m}^{-2} \cdot \mathrm{s}^{-1}\right)$ in the greenhouse whereas plants maintained under a $75 \%$ shade cloth received only $22.5 \%$ $\left(\cong 400 \mu \mathrm{mol} \cdot \mathrm{m}^{-2} \cdot \mathrm{s}^{-1}\right)$ of PAR.

Growth of plants under $90 \%$ and $22.5 \%$ of PAR - To evaluate the effects of light intensity upon growth and development, ten plants were used, drawn at random from the pool of plants. The experiment was followed for 173 days, along which data collection was performed nine times.

For determination of the pseudobulb volume, a correlation with the volume of a conic section was used, since a pseudobulb has the approximate form of two conic sections juxtaposed through their base. Thus, the volume of one pseudobulb was calculated as follows:

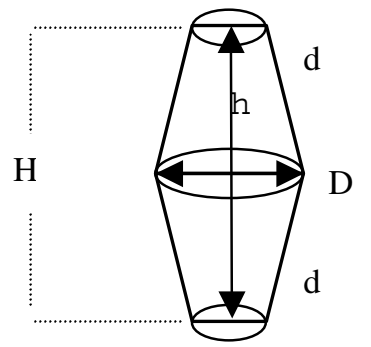

$\mathrm{V}_{\mathrm{pb}}=2 \cdot\left\{1 / 3 \cdot \mathrm{p} \cdot \mathrm{h} \cdot\left[(\mathrm{d} / 2)^{2}+\mathrm{d} / 2 \cdot \mathrm{D} / 2\right.\right.$
$\left.\left.+(\mathrm{D} / 2)^{2}\right]\right\}$, where
$\mathrm{V}_{\mathrm{pb}}=$ volume of the pseudobulb,
$\mathrm{D} / 2=$ larger semidiameter and
$\mathrm{d} / 2=$ smaller semidiameter
$\mathrm{h}=$ height and $\mathrm{H}=2 \mathrm{~h}$

Leaf area was determined by measurements of length and width of leaves by use of a correlation factor $(0.798)$, determined by linear regression between the actual area and the respective length and width measurements.

The experiment was outlined with two treatments, nine samplings with five replicates and the statistical analyses were $\mathrm{F}$ test and Tukey's test, $\mathrm{p}<0.05$.

Photosynthetic performance and gaseous exchange under $90 \%$ and $22.5 \%$ of PAR - In this experiment, nine plants were used, six of which were under $22.5 \%$ and three under $90 \%$ of PAR. Measurements of fluorescence, transpiration and diffusive resistance were performed in leaves 3 and 5. A diagram of the sympodial orchid used in this work is shown below, with the key numbers for leaves (LF) and pseudobulbs (PB). As higher the number, younger is the shoot:
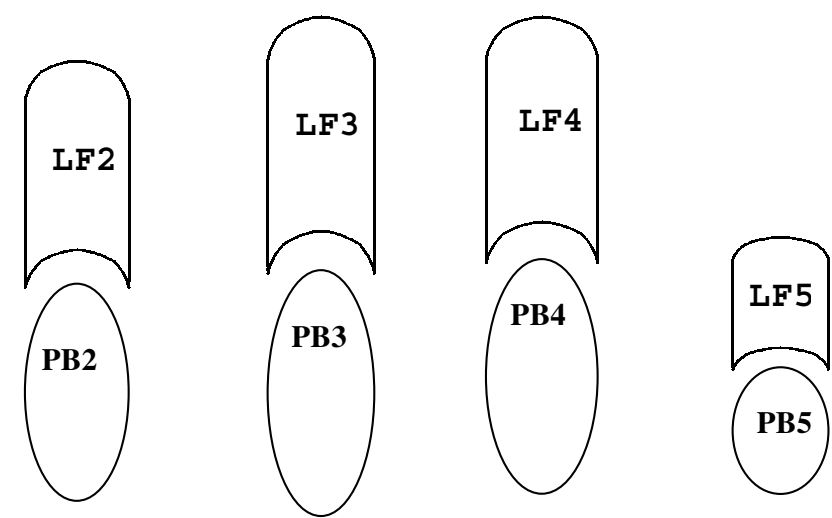

Rhizome 
Seven measurements were performed throughout one night and one day (at 173 days), at the following times: $1 \mathrm{~h}$ dark, $6 \mathrm{~h}$ dark, $14 \mathrm{~h}$ dark ( $0 \mathrm{~h}$ light), $1 \mathrm{~h}$ light, $2 \mathrm{~h}$ light, $4 \mathrm{~h}$ light and $8 \mathrm{~h}$ light.

Chlorophyll fluorescence was measured with a fluorometer (Hansatech, PEA), and a Li-Cor steady-state porometer (LI-1600) was used to measure diffusive resistance and transpiration. The measurements were non-destructive and made upon the same leaves, each time. The diffusive resistance was measured at all sampling times while chlorophyll fluorescence measurements were made on the $4^{\text {th }}, 5^{\text {th }}, 6^{\text {th }}$, and $7^{\text {th }}$ sampling, i.e. from $1 \mathrm{~h}$ of light onwards.

At the $5^{\text {th }}$ sampling, three plants that had grown under $22.5 \%$ of PAR were transferred, immediately after the measurements, to $90 \%$ of PAR. From then on these plants were monitored under those light conditions until the end of the experiment.

The three treatments consisted of plants kept under $22.5 \%$ of PAR, plants kept under $90 \%$ of PAR and plants transferred from $22.5 \%$ to $90 \%$ of PAR. Measurements were performed in three replicates at seven and four time intervals (two leaves per plant), and data were subjected to variance analysis and Tukey's test $(\mathrm{p}<0.05)$.

\section{Results and Discussion}

Daily performance of plants under different levels of irradiance - Data on figure 1 (A, B, C and D) show that plants under $22.5 \%$ of PAR presented the largest stomatal aperture after six hours in the dark. However, in plants under $90 \%$ of PAR, the maximum stomatal aperture was reached only after fourteen hours in the dark. At the peak, the levels of transpiration (figure 1A and C) were higher and the levels of diffusive resistance (figure 1B and D) were lower in plants under $22.5 \%$ of PAR than those plants under $90 \%$ of PAR, showing a variation of $75 \%$ and $70 \%$, respectively.

The transpiration may be considered as a suitable parameter to evaluate the performance of this epiphytic orchid in relation to irradiance levels, since plants under $22.5 \%$ of PAR exhibited a behaviour characteristic of the epiphytic habitat, opening the stomata during the most humid period, that is, at night. Plants under $90 \%$ of PAR showed less sensitivity to variations in relative humidity, presenting greater capacity for gaseous exchange with the atmosphere, right at dawn.

Although in a plant with CAM type metabolism, stomatal aperture can not be used directly to deduce quantitatively $\mathrm{CO}_{2}$ assimilation, our data afford the speculation that the characteristics described probably mean that plants subjected to $22.5 \%$ of PAR show higher rates of atmospheric $\mathrm{CO}_{2}$ assimilation, as well as a

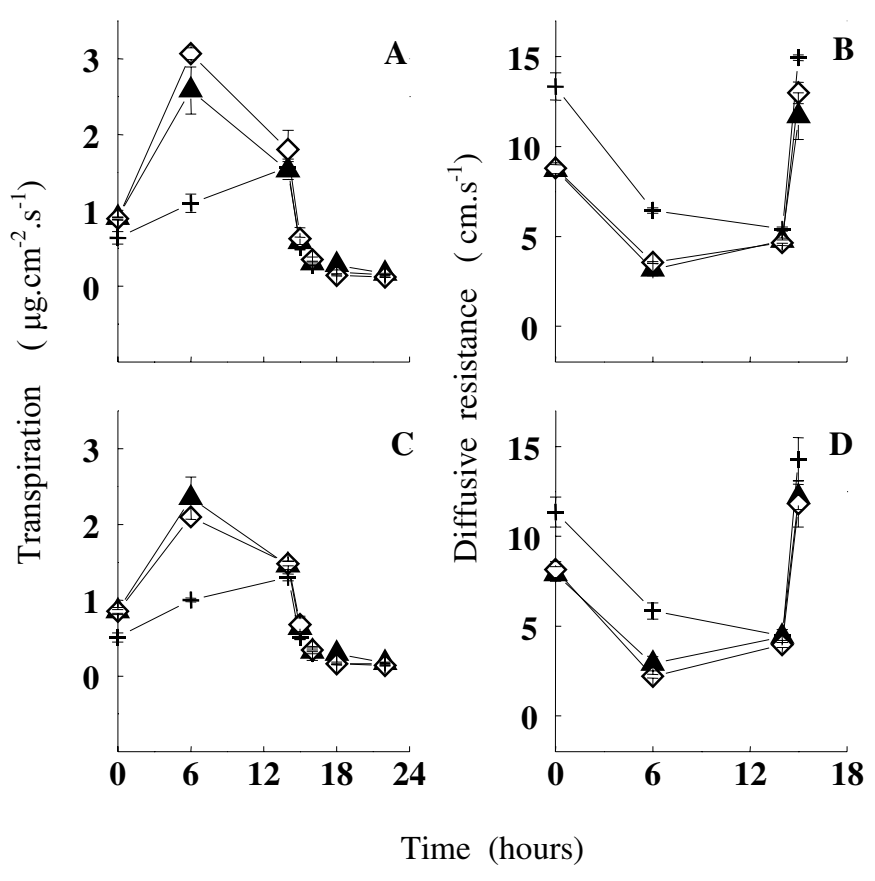

Figure 1. Transpiration (A, C) and diffusive resistance (B, D) in leaf $5(\mathrm{~A}, \mathrm{~B})$ and $3(\mathrm{C}, \mathrm{D})$ of the epiphytic orchid C. forbesii X L. tenebrosa kept under $90 \%$ (+), under $22.5 \%$ $(\boldsymbol{\Delta})$ and plants transferred from 22.5 to $90 \%(\diamond)$ of PAR after two hours of light. The measurements were initiated during the dark period and continued in the subsequent light period. The points represent averages (three replicates) and bars standard errors.

greater flow of water towards the leaves, since they maintain their stomata open for a longer period of time during the night. Indeed, CAM plants from other families can present morphological and physiological differences when cultivated under high light intensity and in the shade (Boardman 1977, Medina 1987, Osmond \& Chow 1988, Lüttge et al. 1991a, Lüttge et al . 1991b, Medina et al. 1991).

Light intensity also affected the efficiency of the photosynthetic process. The $F_{v} / F_{m}$ ratio is proportional to the rate of photosynthesis of intact leaves (Björkman $\&$ Demmig 1987) and was higher in plants under $22.5 \%$ of PAR (figure $2 \mathrm{~A}$ and B). In plants under $90 \%$ of PAR, the $F_{v} / F_{m}$ ratio clearly shows some degree of photoinhibition (figure $2 \mathrm{~A}$ and $\mathrm{B}$ ). This phenomenon can be quickly induced by transference from low to high light intensity, as has been demonstrated by the gradual decrease in $\mathrm{F}_{\mathrm{v}} / \mathrm{F}_{\mathrm{m}}$ ratios of LF 5 and LF 3 from 0.84 to 0.73 and 0.69 respectively. In addition, these results indicate that LF 3, an older leaf, is relatively more sensitive to light stress. Through visual inspection, it could be inferred that plants grown under $90 \%$ of 
PAR displayed a chlorotic aspect. This suggests the limitation of photoprotection mechanisms, including the imbalance between the biosynthesis and degradation of accessory and heat dissipating photosynthetic pigments in the leaf.

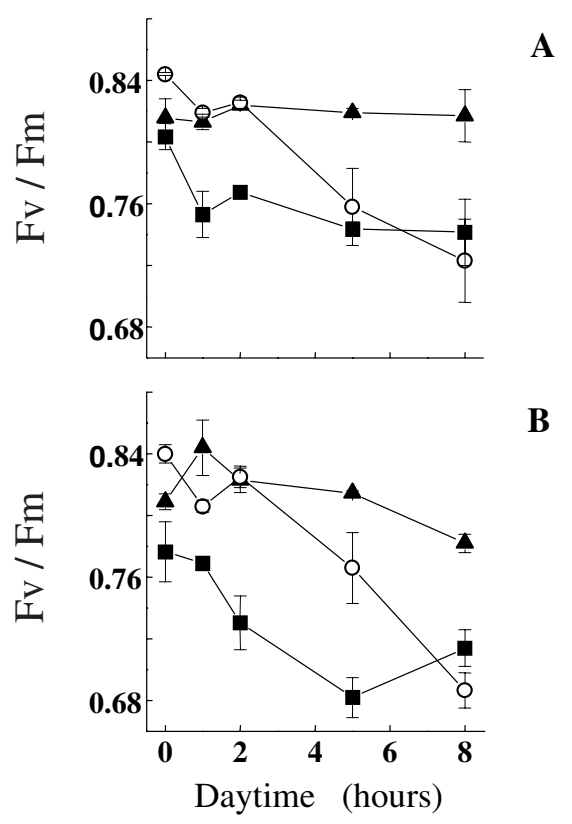

Figure 2. Fluorescence measurements obtained for leaves 5 (A) and 3 (B) in the epiphytic orchid C. forbesii $\mathrm{X}$ L. tenebrosa during daytime, with plants under $90 \%(+)$, under $22.5 \%(\Delta)$ and plants transferred from $22.5 \%$ to $90 \%$ $(\diamond)$ of PAR after two hours of light. The zero hour corresponds to $8 \mathrm{am}$. Points represent averages (three replicates) and bars standard errors.

The transfer of some plants from $22.5 \%$ to $90 \%$ of PAR has shown how this orchid responds to a sudden exposure to high levels of irradiance, tending gradually to behave similarly to those maintained for longer periods under this condition. After the transfer, a rapid reduction in the photosynthetic efficiency of these plants might have occurred, reinforcing the possibility of the occurrence of photoinhibition (Björkman \& Demmig 1987). In fact, it has been proposed that CAM type plants grown in the shade may be sensitive to photoinhibition (Adams \& Osmond 1988).

It is probable that under $90 \%$ of PAR plants were also exposed to high temperatures, which might have induced injury to the photosynthetic apparatus, mimicking the effects of photoinhibition. This fact agrees with the findings of Medina et al. (1986) and Medina (1987) who demonstrated that some epiphytic orchids native to tropical and subtropical forests incorporate atmospheric $\mathrm{CO}_{2}$ at night, and show photoinhibition when exposed to higher levels of irradiance.

The behaviour of the stomata of plants under $90 \%$ of PAR (figure 1) could be contributing towards an increase in the leaf internal temperature, avoiding thermal exchanges with atmosphere at night.

Long-term performance of plants under different conditions of irradiance - The changes in leaf area of plants of Cattleya forbesii X Laelia tenebrosa growing under two levels of light intensity are presented in figure 3 . These results show that light intensity interfered with growth and development of this orchid. From the beginning of the experiment, the plants cultivated under $22.5 \%$ of PAR exhibited a larger leaf area than plants cultivated under $90 \%$ of PAR, the difference being related to LF 4 and LF 3, but not LF 2 .

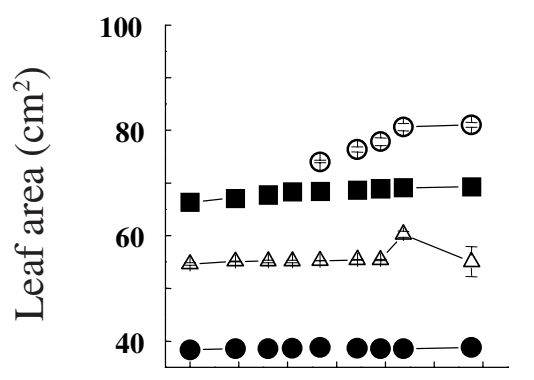

$\mathbf{A}$

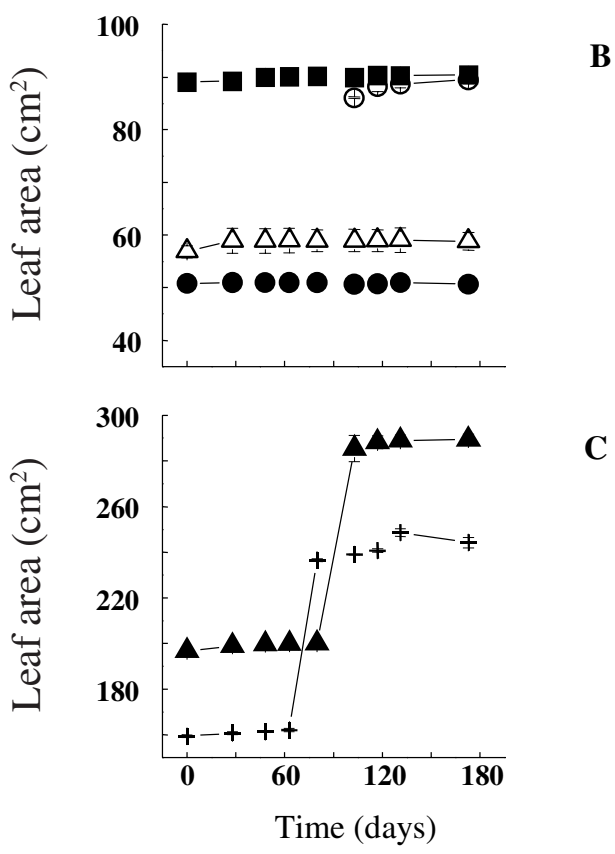

Figure 3. Leaf area measurements of the epiphytic orchid C. forbesii X L. tenebrosa cultivated in a greenhouse under 90 or $22.5 \%$ of PAR, for 173 days. (A) $(90 \%)$ and (B) $(22.5 \%)$ show the variation on each leaf in the plants. (C) total leaf area per plant under $22.5(\%)$ or $90 \%(+)$ of PAR. Points represents the averages (five replicates) and bars mean standard errors. [ $\bigcirc$ leaf 5 , $\square$ leaf 4 , $\bullet$ leaf $3, \triangle$ leaf 2 ]. 
During the period of observation, both groups of plants developed new leaves (figure 3). Plants maintained under $90 \%$ of PAR started to develop a new leaf (LF 5) after 80 days (figure $3 \mathrm{~A}$ ), whereas under $22.5 \%$ of PAR the appearance of LF 5 occurred only after 103 days from the start of the experiment (figure 3B). With the development of LF 5, the total leaf area increased by ca $40 \%$ and $50 \%$ for $22.5 \%$ and $90 \%$ of PAR respectively (figure $3 \mathrm{C}$ ).

The data on figures $4 \mathrm{~A}$ and $4 \mathrm{~B}$ show that all pseudobulbs underwent reversible changes in their volumes. These organs are chronologically related to the appearance of the youngest shoot, and their development was independent of light intensity. Under $90 \%$ of PAR, the volume of PB 4 decreased linearly from 30 to 100 days and after 180 days increased to a level similar to the initial. This suggests that part of storage compounds of this pseudobulb might have been transferred to the current shoot (LF 5 and PB 5), as previously observed by Stancato et al. (2001). The present observation can be compared with the changes in the plants maintained under $22.5 \%$ of PAR in which a decrease in volume was observed from 60 to 90 days with a relatively quick recovery to higher levels at 120

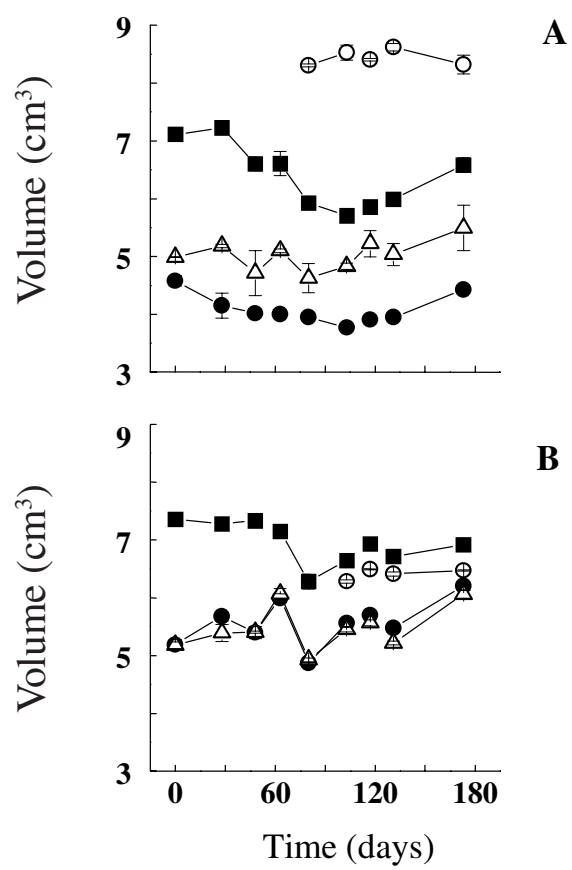

Figure 4. Variation of pseudobulb volume in plants of the epiphytic orchid C. forbesii X L. tenebrosa maintained under greenhouse conditions (22.5\% or $90 \%$ of PAR) for 173 days. (A) plants subjected to $90 \%$, and in (B) subjected to $22.5 \%$ of PAR. Point represent averages (five replicates) and bars mean standard errors. [O pseudobulb 5, $\mathbf{\square}$ pseudobulb 4, pseudobulb 3, $\triangle$ pseudobulb 2]. days. All the back shoots apparently mobilised some of their reserves (glucomannan, according to Stancato et al. 2001) transiently with faster recovery under $22.5 \%$ than under $90 \%$ of PAR (figure 4). This coincided with development of LF 5 and PB 5, suggesting that the current shoot is a sink and PB 4 is possibly the main source. Concerning this source-sink relationship, a distinction can also be made between plants growing under different light intensities. Whereas under $90 \%$ of PAR PB 4 and PB 3 present transient mobilisation, under $22.5 \%$ of PAR PB 5 seems to be a stronger sink.

Zimmerman \& Whigham (1992) found that the water-soluble carbohydrates present in the underground corm of the orchid Tipularia discolor were hydrolysed and were important as a support for the beginning of the new season of growth. On other hand, studies on translocation in the Liliaceae indicated that the beginning of growth is accomplished at the expense of storage carbohydrates, but the subsequent growth and blooming are supported by photosynthesis (Ho \& Rees 1976, 1977).

Stancato et al. (2001) observed that water-soluble carbohydrates (predominantly glucomannan) are present in pseudobulbs (10-30\% of the dry mass, depending on the age) and leaves (3-5\% of the dry mass) of plants of Cattleya forbesii $\mathrm{X}$ Laelia tenebrosa.

Altogether, our results indicate that these carbohydrates might be involved in the transfer of storage compounds from the older to the youngest pseudobulb and to the developing leaf, to be used for growth and development. It is likely that after the initial growth, the reserves in older pseudobulbs would be replaced by the newly produced photoassimilates. Such features were described for the terrestrial orchids Orchis morio by Franz \& Meier (1971) and for Tipularia discolor by Zimmerman \& Whigham (1992) and for epiphytic orchids such as Catasetum viridiflavum (Zimmerman 1990), Dendrobium (Wadasinghe \& Hew 1995) and Spatoglottis unguiculata and Bromheadia finlaysoniana (Hew et al. 1998).

Our daily evaluations of the photosynthetic apparatus showed that plants under $90 \%$ of PAR presented photoinhibition and therefore plants under $22.5 \%$ of PAR displayed a more efficient carbon assimilation system. If this situation persisted during 173 days of the long-term experiment, it is possible that the occurrence of photoinhibition might be related to the long-term reserve mobilisation in the pseudobulbs. This might even have been reflected into the source- 
sink transition of the newly produced leaves of the plants cultivated under the two light intensities used. Indeed, LF 5 of plants under $90 \%$ of PAR appeared before the recovery of the levels of reserve in PB 4 which started after 80 days. This suggests that LF 5 might have contributed for its recuperation. On the other hand, LF 5 of plants under $22.5 \%$ of PAR appeared 103 days after reserve degradation was completed. This probably occurred because leaves 1-4 were capable to assimilate carbon more efficiently, resulting in a shorter reserve mobilisation period. In this case, the other leaves probably supported recovery.

Our results indicated that dry mass partitioning of plants of the hybrid C. forbesii X L. tenebrosa was affected by the light conditions in which they were cultivated. In the case of plants that grew under higher light intensity, development was relatively more dependent on the storage compounds of pseudobulbs. On the other hand, for plants cultivated under low light intensity, the development of the new shoot was dependent on both PB storage compounds and the actual photosynthetic capacity. Thus, for the hybrid studied in this work, an appropriate level of light favours a more efficient resource management, so that development of the new shoots and flowers are assured.

\section{References}

ADAMS, W.W. \& OSMOND, C.B. 1988. Internal $\mathrm{CO}_{2}$ supply during photosynthesis of sun and shade grown CAM plants in relation to photoinhibition. Plant Physiology 86:117-123.

BJÖRKMAN, O. \& DEMMIG, B. 1987. Photon yield of $\mathrm{O}_{2}$ evolution and chlorophyll fluorescence characteristics at $77 \mathrm{~K}$ among vascular plants of diverse origin. Planta 170:489-504.

BOARDMAN, N.K. 1977. Comparative photosynthesis of sun and shade plants. Annual Review of Plant Physiology 28:355-377.

FRANZ, G. \& MEIER, H. 1971. Bildung und Abbau des Schelimpolysaccharids (salepmannan) vos Orchideenknollen. Planta Medica 19:326-332.

HEW, C.S., KOH, K.T. \& KHOO, G.H. 1998. Pattern of photoassimilate partitioning in pseudobulbous and rhizomatous terrestrial orchids. Environmental and Experimental Botany 40:93-104.

HO, L.C. \& REES, A.R. 1976. Re-mobilization and redistribution of reserves in the tulip bulb in relation to new growth until anthesis. New Phytologist 76:59-68.

HO, L.C. \& REES, A.R. 1977. The contribution of current photosynthesis to growth and development in the tulip during flowering. New Phytologist 78:65-70.
HOAGLAND, D.R. \& ARNON, D.I. 1950. The water culture method for growing plants without soil. California Agricultural Experimental Station, Circular n. 347. California.

KEILLER, D.R., SLOCOMBE, S.P. \& COCKBURN, W. 1994. Analysis of chlorophyll $a$ fluorescence in $\mathrm{C}_{3}$ and CAM forms of Mesembryanthemum crystallinum. Journal of Experimental Botany 45:325-334.

KNUDSON, L. 1946. A new nutrient solution for germination of orchid seed. American Orchid Society Bulletin 15:214-217.

LÜTTGE, U. 1989. Vascular plants as epiphytes: Evolution and Ecophysiology (U. Lüttge, ed.). Spring-Verlag, Heidelberg.

LÜTTGE, U., BALL, E., FETENE, M. \& MEDINA, E. 1991a. Flexibility of crassulacean acid metabolism in Kalanchoe pinnata (Lam.) Pers. I. Response to irradiance and supply of nitrogen and water. Journal of Plant Physiology 137:259-267.

LÜTTGE, U., BALL, E. \& FETENE, M. 1991b. Flexibility of crassulacean acid metabolism in Kalanchoe pinnata (Lam.) Pers. II. Light-use characteristics of plants grown in low or high light. Journal of Plant Physiology 137:268-272.

MEDINA, E. 1987. Aspectos ecofisiológicos de plantas CAM en los trópicos. Revista de Biologia Tropical 35(supl. 1):55-70.

MEDINA, E., OLIVARES, E. \& DIAZ, M. 1986. Water stress and light intensity effects on growth and nocturnal acid accumulation in a terrestrial CAM bromeliad (Bromelia humilis) under natural conditions. Oecologia 70: 441-446.

MEDINA, E., POPP, M., LÜTTGE, U. \& BALL, E. 1991. Gas exchange and acid accumulation in high and low irradiance grown pineapple cultivars. Photosynthetica 254:489-498.

OSMOND, C.B. 1978. Crassulacean acid metabolism: a curiosity in context. Annual Review of Plant Physiology 29:379-414.

OSMOND, C.B. \& CHOW, W.S. 1988. Ecology of photosynthesis in the sun and shade: summary and prognostications. Australian Journal of Plant Physiology 15:1-9.

STANCATO, G.C., MAZZAFERA, P. \& BUCKERIDGE, M.S. 2001. Effect of a drought period on the mobilisation of non structural carbohydrates, photosynthetic efficiency and water status in an epiphytic orchid. Plant Physiology and Biochemistry 39:1009-1016.

WADASINGHE, G. \& HEW, C.S. 1995. The importance of back shoots as a source of photoassimilates for growth and flower production in Dendrobium cv. Jashika Pink (Orchidaceae). Journal of Horticultural Science 70:207-214. 
WINTER, K., WALLACE, B.J., STOCKER, G.C. \& ROKSANDIC, Z. 1983. Crassulacean acid metabolism in Australian vascular epiphytes and some related species. Oecologia 57:129-141.

WINTER, K. \& GADEMANN, R. 1991. Daily changes in $\mathrm{CO}_{2}$ and water vapour exchange, chlorophyll fluorescence and leaf water relations in the halophyte Mesembryanthemum crystallinum during the induction of Crassulacean Acid Metabolism in response to high salinity. Plant Physiology 95:768-776.
ZIMMERMAN, J.K. 1990. Role of pseudobulbs in growth and flowering of Catasetum viridiflavum (Orchidaceae). American Journal of Botany 77:533-542.

ZIMMERMAN, J.K. \& WHIGHAM, D.F. 1992. Ecological functions of carbohydrates stored in corms of Tipularia discolor (Orchidaceae). Functional Ecology 6:575-581. 